\title{
NAISET JA KANSANSIVISTYKSEN SUURI KERTOMUS
}

KANSANSIVISTYSAATE vaikuttaa ajautuneen sivistyspoliittisen keskustelun marginaaliin Suomessa. Vaikka kansansivistys, nykyiseltä käsitteeltään vapaa sivistystyö, koskee vuosittain miljoonaa ihmistä, se saa vähän huomiota ja on käsitteenä suurelle yleisölle melko tuntematon. Miten kansaa sitten sivistetään? Yhden näkökulman tuo televisiossa meneillään oleva ohjelma Sivistyksen käsikirja. Sen tarkoitus näyttää olevan haastaa länsimaisen kulttuurin sivistystraditio jakamalla informaatiota jälkimoderneille lunttaajille television välityksellä juuri sen verran, että he voivat bluffata itsensä sivistyneistön joukkoon. Sen sijaan kansalaisten into oppia uutta yhteisöllisesti kansalais- ja työväenopistoissa ei kiinnosta suurta yleisöä. Vapaan sivistystyön historialliset juuret ovat kadoksissa ja tulevaisuudenkuva on epäselvä. Mitä on vapaa sivistystyö tulevaisuudessa, ja onko jo syytäkin sanoutua irti menneisyyden muisteluista?

Kansalais- ja työväenopistoista on kehittynyt sadassa vuodessa naisvaltaisia instituutioita. Opistojen rehtoreista yli puolet oli naisia vuonna 2008. Samaan aikaan peruskoulujen rehtoreista naisia oli reilusti alle puolet. Opistojen opiskelijoista kolme neljästä oli naisia. Myös suuri osa opiston opettajista ja muusta henkilökunnasta oli naisia. Kun Suomen kansalais- ja työväenopistoissa opiskelee vuosittain yli 600000 opiskelijaa, opistoilla on merkittävä si- vistystehtävä erityisesti naisten tietojen ja taitojen kartuttajana. Sukupuolesta on kehittynyt vapaassa sivistystyössä merkittävä sivistyspoliittinen tekijä, ja siitä on haluttu vaieta.

\section{ONKO SUKUPUOLELLA MERKITYSTÄ?}

Onko sukupuolella merkitystä kansalais- ja työväenopiston johtamisessa? Tähän suuntaan antavat viitteitä sekä peruskoulun rehtoritutkimukset että muu työelämätutkimus. Omassa tutkimuksessani ymmärrän sukupuolen yhteiskunnallisten suhteiden järjestelmäksi, joka liittyy työelämän sukupuolijärjestelmän käsitteeseen. Postmodernin naistutkimuksen tulkinnoin sukupuolta tuotetaan erilaisin kulttuurisin järjestyksin, toistoin ja rikkomisin. Tieteellisyys edellyttää kriittisyyttä, ja olen tutkimuksessani lähestynyt aineistoja sukupuolisensitiivisesti feminiinisellä lähestymistavalla. Olen tulkinnut niitä kriittisesti ja nostanut esiin sukupuolten välisiä valtasuhteita ja epäkohtia.

Väitöskirjatutkimukseni yhdistää toisiinsa kansansivistyshistorian, sukupuolen sekä kansalais- ja työväenopistojen johtajuuden. Tavoitteeni oli selvittää, kuinka kansansivistyksen historialliset kehityslinjat 1800-1900-luvuilla kiinnittyvät kansalais- ja työväenopistojen johtajuuteen 2000-luvulla sukupuolen näkökulmasta tarkasteltuna kansan, sivistyksen 
ja vapauden käsitteiden tulkinnoissa. Tavoitteenani oli jäljittää kansansivistyshistorian kadonneita naisia. Tutustuminen kulttuurihistorialliseen aineistoon johti matkalle kansansivistyksen suureen kertomukseen, monenlaisiin kulttuurisiin ja sosiaalisiin merkityksiin, joilla kansansivistysideologiaa yli sadan vuoden ajan oikeutettiin ja ylläpidettiin. Historiallisena aineistona olivat kansansivistäjien ohjelmalliset tekstit, historiikit sekä lehdistöaineisto ja empiirisenä aineistona kansalais- ja työväenopistojen rehtorikysely vuodelta 2005.

\section{KANSANSIVISTYSTÄ, KEILLE?}

Käsite kansansivistyksestä on muuttunut yhteiskunnallisten ja kulttuuristen tekijöiden vaikutuksesta. Kirkko kansanvalistajana suuntasi hengellisen valistuksensa aluksi lähinnä mieskansalaisille. 1800-luvun kansallistamisaate nosti esiin velvoitteen kansanopetuksesta. Se perustui J. V. Snellmanin sivistysideologiselle periaatteelle: Kansa on sivistettävä. Siinä naiselle perhepiirissä toimivana äitinä ja vaimona yleissivistys oli riittävä sivistyksen muoto. Mies julkisuudessa toimivana puolestaan tarvitsi korkea-asteen sivistystä. 1900-luvun vaihteessa käytettiin rinnakkain käsitteitä kansanvalistus, kansansivistystyö, vapaa sivistysharrastus ja vapaa kansansivistystyö. 1920-luvulla otettiin käyttöön käsite vapaa kansansivistystyö toiminnan tunnustamisen ja rahoituksen perustaksi. Lainsäädännön myötä vuonna 1962 sana kansa jätettiin käsitteestä pois, ja käyttöön tuli nykyinen käsite, vapaa sivistystyö.

1800-luvun kollektiivisesti sivistettävästä kansasta muotoutui 1900-luvulla itseään vapaa-ajalla sivistävä yksilökansalainen. Tämän muutoksen seurauksena korostuivat yksilön valinnan vapaus ja kansalaisen vapaus sivistää itseään. Sadan vuoden matkalla sivistyksen käsite katosi, ja sen korvasi tavoitteellinen koulutus ja opinnoissa viihtyminen. Työ -sanan säilyminen käsitteen nimessä kiinnitti yksilön uusliberalistisen ajattelun mukaiseen hyvään kansalaisuuteen ja ahkeraan työntekijään osana teollisen yhteiskunnan taloudellisen kasvun ideaalia.

Kansansivistyksen tehtäväksi historiallisesti tarkasteltuna määrittyi erilaisten kansalaisryhmien yhdistäminen ja muuttuvien yhteiskunnallisten olojen tukeminen. 1800-1900-lukujen vaihteessa kansansivistys liittyi osaksi laajaa kansallistamishanketta, jossa sivistyksellä pyrittiin lisäämään yksittäisten kansalaisten ja sitä kautta koko kansakunnan hyvinvointia. Kansansivistysdiskurssissa kansa esitettiin sivistyksen kohteena, objektina, jota sivistyneistö halusi holhota. Vuosisadan vaihteessa kansansivistys tuki Suomen itsenäisyyden saavuttamista ja kansallista valtioelämää. Kansansivistys sai merkittävän tehtävän kasvattaa suomalaisista yhteiskunnallisesti vapaita ja kansanvaltaisia kansalaisia. Tavoitteena oli sivistynyt ihminen, joka toimi koko yhteiskunnan hyväksi eikä uhannut toimillaan yhteiskuntarauhaa. Poliittisesti ja yhteiskunnallisesti epävakaina aikoina, kuten vuoden 1905 suurlakko ja vuoden 1918 sisällissota, kansansivistys yhdisti eri kansalaisryhmiä. Talvi- ja jatkosodan aikana vapaa kansansivistystyö vahvisti kansallista yksimielisyyttä ja sisäistä eheyttä osana kansallisvaltiota. Sotien jälkeen vapaa kansansivistystyö yhdisti henkisesti Suomen kansaa.

\section{UUSLIBERALISMI KAUPALLISTAA}

Suomalaisen aikuiskoulutuspolitiikan murroskausi ajoittui 1970-1980-luvuille. Silloin aikuiskoulutusjärjestelmä liittyi osaksi uusliberalistista kasvun, kaupan ja tehokkuuden ideaalia, jossa vapaan sivistystyön tehtävä kaupallistui. Sen oli tuloksellisesti sivistettävä yksilöä työelämän tarpeita vastaavaksi, osaavaksi ja työssään jaksavaksi. Vapaa sivistystyö ajautui taloudellista tuottoa tavoittelevan koulutusjärjestelmän marginaaliin. Koska kunnilla ei ollut lakisääteistä velvollisuutta rahoittaa opistojen toimintaa, niiden toiminta hankaloitui, projektitapaistui ja valtion taloudellisesta tuesta tuli niille ensiarvoisen tärkeää. Samalla uusliberalismin kasvun, kaupan ja tehokkuuden ideaalit heikensivät vapaan sivistystyön humanistista arvopohjaa. Vuoden 2005 rehtoriaineistossa vapaan sivistystyön merkityksistä korostuivat alueellisen tasa-arvon turvaaminen, sosiaaliset ja psyykkiset sekä sivistykselliset ja kulttuuriset merkitykset. Tässä tilanteessa voikin kysyä, olisiko vapaan sivistystyön syytä kirkastaa valtiollista sivistystehtäväänsä erilaisten kansanosien yhdistäjänä 2000-luvun monikulttuuristuvassa ja kansainvälistyvässä Suomessa? 
2000-luvulle tultaessa kansansivistyksen suuri kertomus jakautuu hajanaisiksi kertomuksiksi, näkökulmiksi ja kamppailuiksi vapaan sivistystyön ja sen toteuttajien kesken. Hyvinvointivaltion politiikkaa toteutetaan tehostamalla julkisten organisaatioiden toimintaa. Niiden on tuotettava valtiolle talouskasvua, kasvavaa kilpailukykyä ja korkeaa työllisyyttä. Kansalais- ja työväenopistot ovat keskellä kansallisen koulutuspolitiikan murroskautta, joka uudistaa julkista palvelurakennetta. Se on osa suomalaista sivistysreformia, joka järjestelee opistoja laajoiksi seutukunnallisiksi opistofuusioiksi eri koulutusaloja yhdistäen ja osana valtakunnallista kuntarakenneuudistusta. Myös kansalais- ja työväenopistojen on tultava osaksi taloudellista tuottoa tavoittelevia aikuiskoulutusmarkkinoita. Tulkitsen opistoreformin osaksi uusliberalismin markkinataloutta, joka tavoittelee sekä työntekijöiden että työyhteisöjen tuloksellista ja mitattavissa olevaa toimintaa. On uusliberalismin hengen mukaista, että opistot julkisina instituutioina pyrkivät itseohjautuviksi ja yrittäjähenkisiksi.

\section{NAISET JA KANSANSIVISTYS}

Kuinka sitten naiset liittyvät mukaan kansansivistyksen kertomukseen? Suomalaisten naisten kansansivistyshistoriaan liittyvät määreet vapaaehtoisuudesta, kollektiivisuudesta ja yleissivistyksellisyydestä. Naisten erityinen aktiivisuus kansanvalistustyössä on ollut suomalaiseen naisliikkeeseen kuuluva erityispiirre, jossa naisliike ja suomalaisuusliike kietoutuivat yhteen. Naiset aktivoituivat sivistämään itseään 1800-luvun lopulta aluksi kollektiivisesti erityisesti naisille tarkoitetuissa vapaaehtoisissa seuroissa ja järjestöissä, joissa aluksi raittiusliikkeellä oli merkittävä rooli. Tässä vapaaehtoisessa sivistystyössä naiset jäsensivät sosiaalista yhteenkuuluvuuttaan ja asemaansa suomalaisessa yhteiskunnassa. Näiden järjestöjen tavoitteet palvelivat aluksi patriarkaalisen yhteiskun- tajärjestelmän mukaisesti perheinstituutiota osana kansanvaltaa ja kotia siveellisen naisen suljettuna elinpiirinä.

1900-luvun alussa perustetut valtiolliset kansalaisja työväenopistot vahvistivat tätä vapaaehtoisen järjestötyön alkuun panemaa naisten sivistystehtävää. Opistot yhdessä vapaaehtoisen järjestötyön kanssa sivistivät suomalaista naista äitikansalaisena, hyväksi lasten kasvattajaksi ja kodin hengettäreksi. Naisten lukumäärä opiston opiskelijoissa kasvoi 1900-luvun alkuvuosikymmeninä, ja opetussisällöt mukautuivat naisten elämäntilanteita vastaaviksi, yleissivistäviksi ja ammatillisiksi kokonaisuuksiksi.

Kansansivistyksen ja koulutusmahdollisuuksien myötä suomalaisesta kotiäidistä kehittyi tasa-arvon tunteva ansioäiti. Vuosisadan vaihteessa naisen asemaan vaikuttaneet yhteiskunnalliset kehitystekijät yhdessä teollistumisen myötä lisäsivät naisten ansiotyöläisyyttä, joka aktivoi naiset hakemaan lisää tietoja ja taitoja. Kansallisen työvoimatarpeen kasvaessa myös työläisnainen tarvitsi yhä enemmän ammatillista sivistystä, mutta toisaalta jaksaakseen ansiotyössä myös virikkeitä heidän vapaa-ajallaan. Kansalais- ja työväenopistoista kehittyi varsin pian paikkoja, joissa naiset saattoivat vapaa-ajallaan kollektiivisesti sivistää ja yleissivistää itseään. Naisista kehittyi kansallisesti merkittävä työvoimaresurssi, jota yhteiskunnan oli tarpeellista sivistää. 2000-luvulla kansalais- ja työväenopistot ovat naisten institutionaalisia itsensä kehittämisen tiloja, joissa he kollektiivisesti saattavat purkaa työelämän paineitaan ja muokata minuuttaan työelämän vaatimusten mukaiseksi. Niistä on mahdollista hakea elämälle mielekkyyttä myös silloin, kun työelämä ei sitä tarjoa.

Tutkimukseni kannalta keskeistä oli kansakoulunopettajaseminaarien avaaminen naisille, koska opettajan tutkinto oli naiselle tie jatko-opintoihin. Aluksi opettajuus ymmärrettiin vapaaehtoisuuteen perustuvaksi kutsumusammatiksi, joka oli naiselle 
erityisen sopiva sen äidillisyyden, hoivaavuuden ja kasvatuksellisen luonteensa vuoksi. Tästä sai alkunsa naisen ura myös opiston johtajattarena ja rehtorina, joka saattoi toteuttaa tehtävässään yhteiskunnallisen äitiyden velvoitetta opistoäitinä. Nainen sopi opiston johtoon hyvin, koska hän opettajana ja johtajattarena saattoi olla tukemassa naisopiskelijoiden sivistykseen liitettyä siveellisyyskäsitystä. Naisten lukumäärän lisääntyminen opiston johdossa liittyi heidän mahdollisuuksiinsa suorittaa yliopistotutkintoja, naisen asemaan vaikuttaneiden valtiollisten ja lainsäädännön uudistusten toimeenpanoon sekä opistojen opiskelijoiden naisvaltaistumiseen.

\section{REHTORI YHTEISKUNNALLISENA TOIMIJANA}

Vuonna 2005 kansalais- ja työväenopiston rehtorista hahmottuu kuva yhteiskunnallisena toimijana, jonka ammatillinen työnkuva on muutoksessa. Erilaiset työyhteisöjen rakennemuutokset näyttävät koskevan erityisesti opistojen rehtoreita. Yhä useampi heistä työskentelee myös kunnan yhdistelmävirassa. Kuten peruskoulun rehtorit, myös opistojen rehtoritkin, ovat työstään uupuneita ja tekevät säännöllisesti ylitöitä. Tärkeää on huomata, että opiston rehtoreissa elää edelleen usko vapaan sivistystyön ideologiaan, ja tehtävään hakeudutaan sen mielekkyyden vuoksi. Julkiselle hallinnonalalle tyypilliseen tapaan sukupuolen merkitystä ei haluta työssä korostaa. Tasa-arvon käsite liitettiin kansansivistysdiskurssissa sivistykselliseen, mutta ei sukupuolten väliseen tasa-arvoon. Naiseen ja mieheen rehtorina liitettiin stereotypioita sukupuolten erilaisista tavoista johtaa organisaatiota. Naisrehtorit kokivat sukupuolestaan toisaalta olevan haittaa opiston johtamisessa. Niihin liittyivät sukupuoleen viittaaminen, vähättely ja kuulematta jättäminen. Aineistoni rehtorit kokivat työssään työyhteisön ulkopuolelta tulevaa arvostuksen puutetta, joka ei samalla tavalla tule esille muissa oppilaitostutkimuksissa. Onko kansalais- ja työväenopistojen naisvaltaisuudella yhteys rehtorien kokemukseen ammattialan heikosta arvostuksesta ja näkyvyydestä?

\section{TUTKIMUSTA SIIS TARVITAAN}

Aikuiskasvatustieteessä vapaata sivistystyötä ja erityisesti kansalais- ja työväenopistoja koskevaa tutki- musta on tuotettu varsin satunnaisesti ja verkkaiseen tahtiin. Väitöskirjatutkimusta ovat tehneet lähinnä opistojen rehtorit, ja tutkimusaiheet ovat liittyneet oman oppilaitosmuodon toimintaan. Tässä suhteessa tämäkään tutkimus ei tee poikkeusta: se on naisrehtorin tutkimus kansansivistyksen historiallisista kehityslinjoista sekä kansalais- ja työväenopiston rehtorin työnkuvan muutoksesta sukupuolen näkökulmasta tarkasteluna. Näenkin, että tulevaisuudessa vapaan sivistystyön tutkimusväylä olisi hyvä liittää osaksi aikuiskasvatustiedettä, jossa systemaattisesti tuotetaan sekä perus- että kehittämistutkimusta. Tärkeää olisi pitää kiinni ministeriön suunnitelmasta luoda vapaalle sivistystyölle oma tutkimusohjelma vuoteen 2012 mennessä.

Tutkimukseni pohjalta kansalais- ja työväenopistojen sivistystehtävää 2000-luvulla määrittävät monet ulkopuoliset tahot ja kansallisesti yhtenäistä sivistysideaalia hajottavat aluepoliittiset olemassaolon taistelut. Vapaan sivistystyön tehtävää osana suomalaista koulutusjärjestelmää onkin syytä tulevaisuudessa tarkastella kriittisesti. Katson, että tutkimukseni antaa sekä kansalais- ja työväenopistoille, niiden ylläpitäjille että alan järjestöille näkökulman hahmottaa kansansivistyksessä sadan vuoden ajalla tapahtuneita muutoksia. Samalla voisi miettiä, olisiko syytä päivittää vapaan sivistystyön ydintehtävät Suomessa 2000-luvun yhteiskunnallisten tilanteiden mukaisiksi.

Lectio väitöstilaisuudessa 22.1.2011. Otsikko ja väliotsikot toimituksen.

Tarja Lang. (2011). Myyttisestä sankarirehtorista opistoäidiksi ja manageriksi. Sukupuolen näkökulma kansalais- ja työväenopiston johtajuuteen. Helsingin yliopiston käyttäytymistieteellinen tiedekunta.

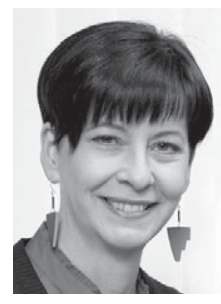

Tarja Lang

KM (väit.), rehtori, Espoon suomenkielinen työväenopisto 